\title{
Occupational Health Hazards as Perceived by Poultry Processing Slaughterhouse Workers
}

\author{
HANAA H. MOHAMMED, M.Sc.*; SANEYA M. RIZK, D.N.Sc.* and EBTESAM M. EBIED, D.N.Sc.** \\ The Departments of Community Health Nursing* and Gerontological Health Nursing**, Faculty of Nursing, Cairo University
}

\begin{abstract}
Background: Poultry workers are exposed to a variety of occupational health hazards on a daily basis.

Aim of the Study: The study aimed to assess occupational health hazards as perceived by poultry processing slaughterhouse workers. A descriptive exploratory research design was utilized.

Material and Methods: Setting; the study was conducted in large poultry slaughterhouse at El-Menofia Governorate. A systematic random sample of 278 poultry workers was selected. one tool was used to collect data which includes 4 parts demographic data, occupational and medical history of worker, health habits and life style and workers' perception of occupational health hazards which consists of knowledge of workers about physical, chemical, mechanical, psychological and biological hazards and self reported practices.
\end{abstract}

Results: Reveals that $46.8 \%$ of workers aged more than 30 years old. Furthermore $71.9 \%$ of workers had unsatisfactory level of knowledge. While $80.6 \%$ of workers had unsatisfactory level of self reported practices. There was a highly statistical significant correlation between the workers' total knowledge and their self reported practices $(p=0.0001)$. There was also a highly statistical significant correlation between workers' educational level, knowledge and self reported practices $(p=0.0001)$.

Conclusion: Study concluded that workers had unsatisfactory level of perception (knowledge and self reported practices) regarding occupational health hazards they are exposed to.

Recommendations: It is recommended to raise workers' awareness about occupational hazards they are exposed to through occupational health programs to promote workers' health, ensure safety and enhance productivity.

Key Words: Occupational hazards - Poultry workers - Workers' perception.

Correspondence to: Dr. Hanaa H. Mohammed, The Department of Community Health Nursing, Faculty of Nursing, Cairo University

\section{Introduction}

WORK is considered a basic part of our life. Most adults spend approximately one-fourth to one-third of their time at work, which become an integral part of their life. Healthy workforce is vital for sustainable social and economic development on a global, national and local level. Therefore, health care professionals should have knowledge about workforce populations, work-related health risk factors and methods used to prevent and control these factors in order to improve workers' health [1]. The poultry industry has undergone phenomenal growth over the past 20 years, made possible by the continuous dedication of those individuals working in different segments of the industry including farms, hatcheries, processing slaughterhouses, and feed mills. Despite this, these personnel are permanently exposed to occupational and environmental health hazards during the course of their poultry processing working steps on a daily basis [2] . Poultry processing involves the use of sharp-bladed instruments to debone, trim and cut the birds into various parts. In many cases, these parts can be processed with seasonings, spices, marinades, or other ingredients for consumers. Secondary processing may also occur where parts are converted to ready-to-eat products such as sausages, or nuggets. Packaging of birds, either in whole or in parts, occurs as a last step prior to shipping to food distribution networks. During these processing and packaging steps, traumatic injuries and musculoskeletal disorders have been the primary health effects reported among workers. Such traumatic injuries may result from the extensive use of knives and other sharp-bladed instruments. Musculoskeletal disorders are of particular 
concern and continue to be common among workers in the poultry processing slaughterhouse. These disorders may result from the cumulative effects of rapid and repetitive movements by the poultry processing slaughterhouse workers [3]. Poultry slaughter and evisceration processes begin with off-loading live poultry from transport trucks, then workers typically shackle the birds in a hanging room after which they are stunned, killed, bledout, and de-feathered. Evisceration, or removal of the birds' internal organs, follows during which the birds are washed and inspected, moreover the birds are placed in chiller baths of water and antimicrobial agents to reduce pathogen loading. A variety of chemicals are present in facilities where poultry slaughter and evisceration occur that may present an occupational hazard. Reports of health effects during poultry slaughter and evisceration have often included eye and respiratory irritation, respiratory symptoms. Temperature extremes, high noise levels, Musculoskeletal Disorders (MSDS) and occupational injuries have also been reported [4]. Food manufacturing has one of the highest incidences of injury and illness among all industries; poultry slaughtering plants have the highest incidence among all food manufacturing industries. Many production jobs in poultry-processing slaughterhouses involve repetitive, physically demanding work. Poultry-processing manufacturer workers are highly susceptible to repetitive strain injuries to their hands, wrists, and elbows. This type of injury is especially common in poultry processing slaughterhouses [5]. Poultry processing slaughterhouse employs many different types of workers. More than half or 54 percent are production workers, including skilled precision workers and less skilled machine operators and laborers. Production jobs require manual dexterity, good hand-eye coordination and in some sectors of the industry, strength. Production workers often stand for long periods and may be required to lift heavy objects or use cutting, slicing, grinding, and other dangerous tools and machines [6]. Many poultry processing jobs involve factors that increase the risk of developing work-related injuries or illness. These factors include risks for musculoskeletal disorders such as carpal tunnel syndrome, and include repetition, force, awkward and static postures. Cold temperatures have been associated with increased injuries as well as musculoskeletal disorders [7]. Workrelated musculoskeletal disorders include cases where the nature of injury or illness involves sprains, strains, tears, back pain, carpal tunnel syndrome, hernia, or musculoskeletal system symp- toms, and connective tissue diseases and disorders. These problems occur when the event or exposure leading to the injury or illness involves bending, climbing, crawling, reaching, twisting, overexertion, or repetition [8]. The personality of the worker, the communication level of coworkers and managers and the overall workplace environment are important factors that form the perceptions each employee holds about his workplace, the way employees perceive their occupations' risks can be quite different from what actually exists. Further, the way managers perceive employee working conditions can differ greatly from what workers actually deal with. It is important that managers and owners invest time and other resources in making perceptions and reality line up at work [9].

Evidence from literature indicates that, poultry processing slaughterhouse workers are permanently exposed to occupational and environmental health hazards during the poultry processing steps on a daily basis. These hazards may be mechanical such as (pain, discomfort, serious injury, musculoskeletal problems), physical as (exposure to high noise-heat and cold), chemical as (respiratory problems resulting from exposure to dust, microorganisms, toxic gases, disinfectants), and biological as (Zoonotic infections) [10]. In developed countries, poultry processing depend on technology more than manual procedures as they have a high level of industrial development. In contrary, the developing countries depend on manual procedures which will expose workers to many occupational health hazards. The developed countries' workers enjoy a free and healthy existence more than their counterparts in the developing countries [11]. According to the National Institute for Occupational Safety and Health (NIOSH) health hazard evaluation report, (2014) poultry processing slaughterhouse include the following health hazards: (57\%) musculoskeletal symptom such as carpal tunnel syndrome, (34\%) reported pain, burning, numbness, or tingling in hands or wrists among the poultry processing slaughterhouse workers at Maryland [12]. There are no studies conducted in Egypt in relation to occupational health hazards as perceived by poultry processing slaughterhouse workers so, carrying out this research will add to the body of nursing knowledge in relation to this area and will shed the light on this problem in Egypt. Furthermore, understanding perceptions of those workers about occupational health hazards of poultry processing slaughterhouse will definitely help in prevention of adverse health effects caused by their working conditions. 


\section{Material and Methods}

\section{Research questions:}

1- What are the occupational health hazards as perceived by poultry processing slaughterhouse workers?

Setting: The study was conducted in one of the largest poultry slaughterhouses at El-Menofia Governorate (Kafr Dawood) from 1-3-2016 till 25-5-2016.

Sample: The total number of workers of this study was calculated to be 278 poultry workers according to the sample size calculator, with confidence level (95\%), confidence interval (5\%) and the population size of poultry workers in this slaughterhouse was 1000. 278 Poultry workers were chosen using systematic random sampling out of 1000 to cover the required sample size.

Research design: A descriptive design utilized to fulfill the aim of the study. Tools for data collection: an occupational health hazards perception questionnaire which was developed by the investigator after extensive review of literature and used to collect data. The study tool was reviewed by a panel of five experts in the field of community health nursing and occupational and environmental medicine to ensure content validity. It included four parts:

First part:Demographic characteristics: As: Age, gender, level of education, marital status, income.

Second part: Occupational and medical history of worker which covered chronic diseases, work related diseases, sick leave, number of daily working hours, duration of work at poultry slaughterhouses, working shifts, body posture during work, problems at work, accidents resulting from work and poultry work effects on their health.

Third part: Health habits and life style: It was used to assess worker's life style such as personal hygiene at work and after finishing work, physical exercise, type of sport, smoking, type of smoking, amount of smoking, duration of smoking, effects of smoking on health, nutrition, healthy diet, breakfast and sleeping hours.

Fourth part: Worker's Occupational health hazards perception: It consisted of knowledge of workers about these hazards such as knowledge of workers about physical, chemical, mechanical, psychological and biological health hazards during working hours and self reported practices such as wearing Personal Protective Equipments (PPE), occupational health programmes and their goals, precautions to avoid exposure to physical, chemical, mechanical, psychological, biological health hazards and to avoid accidents at work environment.

Procedure: The formal approvals were obtained from Faculty of Nursing, Cairo University, Scientific Research Ethics Committee and the directorate of the poultry slaughterhouse. Workers were asked to participate in the study, and the investigator explained the aim of the study to all workers. Also written consent was obtained from every participant who accepts to participate. Data was collected from February 2015 till May 2016. Data collected through face to face interviewing schedule with workers who can't read and write without any interference or clarity and the other workers who can read and write took the questionnaire and filled out carefully, this took place in their rest room during worker's break time (breakfast and lunch hour) for at least 15 minutes for 2 days/week.

Ethical considerations: Primary approval was obtained from the Research Ethics Committee at Faculty of Nursing-Cairo University. The investigator informed poultry workers about the purpose and nature of the study. The investigator emphasized that participation in this study is voluntary; each subject has the right to withdraw from the study when he wants. Anonymity and confidentiality was assured through coding of the data. Subjects were assured that this data will not be reused in another research without their permission, and the data collected will be used only for the research. Written informed consent was obtained from each worker.

\section{Statistical analysis:}

The collected data was scored, tabulated and analyzed by personal computer using the recent Statistical Package for the Social Sciences (SPSS) program. Descriptive statistics such as mean and standard deviation were utilized in analyzing data. Chi-square test $\left(X^{2}\right)$ was used to identify the relation among the study variables. This test was used to identify the significance of the relation, association and interaction among poultry workers' knowledge and their self reported practices inside poultry slaughterhouse. The level of significance, threshold of significances is fixed at the 5 percent ( $p$-value). The $p$-value $>0.05$ indicates non-significant result. The $p$-value $<0.05$ is significant. The $p$-value $<0.01$ indicates highly statistically significant difference. 


\section{Results}

Table (1) shows that, $46.8 \%$ of workers were more than 30 years old while $36.3 \%$ of workers were between $20-30$ years and $16.9 \%$ of them were less than 20 years old. As regards workers' gender $53.9 \%$ of participants were male while $46.1 \%$ of them were female. Table (1) also reveals that $1.4 \%$ of workers had enough income and more while $39.2 \%$ of them had enough income whereas $59.4 \%$ of workers had not enough income. Regarding marital status, (Table 1) also reveals that $67.9 \%$ of workers were married and $3.9 \%$ of them were widow while $5 \%$ of workers were divorced also $23.2 \%$ of them were single. The table also illustrates that $67.9 \%$ of workers had technical secondary education, while $12.3 \%$ of workers had university education and $7.6 \%$ of them couldn't read or write whereas workers who can read and write constitute $4.3 \%$ of them, moreover $5.4 \%$ of workers had basic education. As such general secondary education represented $2.5 \%$ of them.

Table (2) shows that $6.5 \%$ of workers worked in poultry slaughterhouses for more than 5 years while $93.5 \%$ of them worked in poultry slaughterhouses for less than 5 years. The table also illustrates that $99.6 \%$ of workers have worked during morning shifts whereas $0.4 \%$ of them have worked during night shifts. Regarding working hours, (Table 2) shows that $43.2 \%$ of workers were working 8 hours daily while $56.8 \%$ of them were working 12 hours daily. The table also reveals that $80.6 \%$ of workers were standing all time during working hours while $17.3 \%$ of them were bending for long periods and $2.1 \%$ of them were sitting during working hours. Moreover, the table illustrates that $70.1 \%$ of workers said that there were problems at work while $29.9 \%$ of them said that there were no problems at work. Moreover $49.2 \%$ of workers mentioned that work is difficult while $37.5 \%$ mentioned bad communication of managers and $13.3 \%$ mentioned no enough salary. The table also shows that $80.5 \%$ of workers had wounds while $19.5 \%$ of them had fractures as a consequence to improper work environment.

Regarding daily physical effort, (Table 3 ) illustrates that $94.9 \%$ of workers mentioned work effort whereas $5.1 \%$ of them played sports as following $78.6 \%$ of them played football while $21.4 \%$ of them run or walked. Furthermore $97.5 \%$ of workers reported practicing this effort regularly while $2.5 \%$ of them mentioned practicing it irregularly. Regarding number of meals per day (Table 3 ) shows that $73.7 \%$ of workers had three meals per day and $18.4 \%$ of them had two meals per day while $7.9 \%$ of them had four meals per day. Moreover when asking about if they thought they eat healthy food, $62.9 \%$ of them said yes moreover $14.4 \%$ of them said no while $22.7 \%$ of workers didn't know. Furthermore $95.7 \%$ of workers ate breakfast regularly while $4.3 \%$ of them did not eat it regularly. Additionally $82.4 \%$ of workers slept more than 6 hours per day while $17.6 \%$ of them slept less than 6 hours per day.

Fig. (1) reveals that $71.9 \%$ of workers had unsatisfactory level of knowledge while $28.1 \%$ of them had satisfactory level of knowledge. Moreover $80.6 \%$ of workers had unsatisfactory level of practice while $19.4 \%$ of them had satisfactory level of practice.

Table (4) shows the correlation between worker's demographic data and knowledge and self reported practices. There was a highly statistical significant correlation between worker's gender and knowledge where male had satisfactory knowledge than female $(p=0.0001)$. Whereas there was no statistical significant correlation found between worker's gender and practice. The table also reveals that there was a highly significant correlation between worker's age and knowledge. Moreover there was a highly significant correlation between worker's age and practice $(p=0.0001)$. Furthermore there was a highly significant correlation between worker's educational level and knowledge and practices $(p=0.0001)$. While there was no relation found between income or marital status and knowledge and practices.

Table (5) shows the correlation between knowledge and practice levels of the workers. There was a highly statistical significant correlation between worker's level of knowledge and worker's level of practices $(p=0.0001)$. Also (Table 5) shows that there was a highly statistical significant correlation between number of meals per day and self reported practices $(p=0.003)$. Also there was a highly statistical significant correlation between worker's daily physical effort and practices $(p=0.001)$. Moreover there was a highly statistical significant correlation between worker's regular effort and practices $(p=0.011)$. Furthermore there was a highly statistical significant correlation between eating healthy food and self reported practices $(p=0.001)$. Moreover there was a highly statistical significant correlation between worker's hours of sleep and self reported practices $(p=0.02)$. While there was no statistical significant correlation found between worker's eating breakfast regularly and self reported practices. 


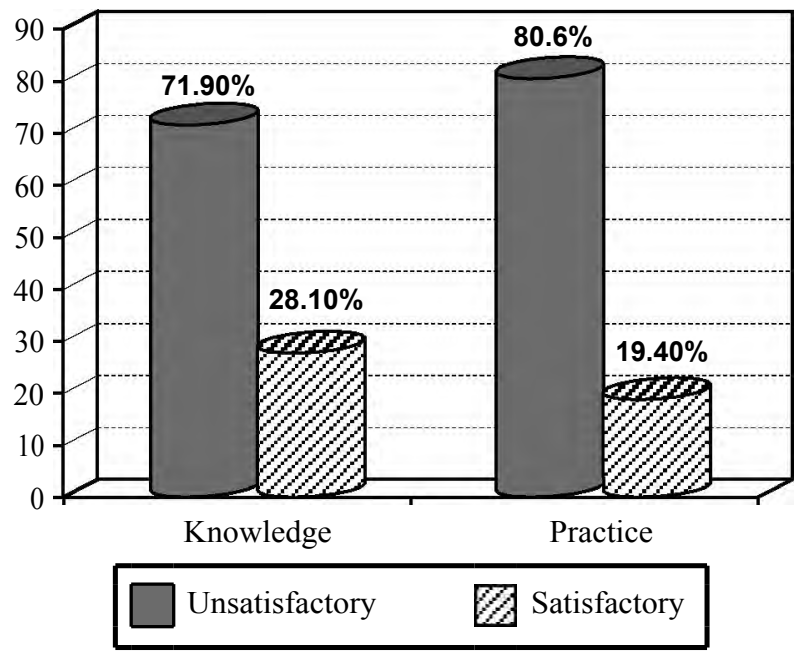

Fig. (1): Shows the levels of knowledge and practice of the sample.

Table (1): Percentage distribution of demographic characteristics of the poultry workers.

\begin{tabular}{|c|c|c|}
\hline Demographic characteristics & No. & $\%$ \\
\hline \multicolumn{3}{|l|}{ Workers' age: } \\
\hline Less than 20 years & 47 & 16.9 \\
\hline Between $20-30$ years & 101 & 36.3 \\
\hline More than 30 years & 130 & 46.8 \\
\hline Total & 278 & 100 \\
\hline \multicolumn{3}{|l|}{ Gender: } \\
\hline Male & 150 & 53.9 \\
\hline Female & 128 & 46.1 \\
\hline Total & 278 & 100 \\
\hline \multicolumn{3}{|l|}{ Income: } \\
\hline Enough and more & 4 & 1.4 \\
\hline Enough & 109 & 39.2 \\
\hline Not enough & 165 & 59.4 \\
\hline Total & 278 & 100 \\
\hline \multicolumn{3}{|l|}{ Marital status: } \\
\hline Single & 64 & 23.2 \\
\hline Married & 189 & 67.9 \\
\hline Divorced & 14 & 5.0 \\
\hline Widowed & 11 & 3.9 \\
\hline Total & 278 & 100 \\
\hline \multicolumn{3}{|l|}{ Educational level: } \\
\hline Can't read and write & 21 & 7.6 \\
\hline Can read and write & 12 & 4.3 \\
\hline Basic education & 15 & 5.4 \\
\hline Technical secondary education & 189 & 67.9 \\
\hline General secondary education & 7 & 2.5 \\
\hline University education & 34 & 12.3 \\
\hline Total & 278 & 100 \\
\hline
\end{tabular}

Table (2): Frequency distribution of workers occupational history $(\mathrm{N}=278)$.

\begin{tabular}{lll}
\hline Occupational history & No. & $\%$ \\
\hline $\begin{array}{l}\text { Duration of work experience at poultry } \\
\text { slaughterhouses: }\end{array}$ & & \\
$\quad$ Less than 5 years & 260 & 93.5 \\
More than 5 years & 18 & 6.5 \\
Others & 0 & 0.00 \\
\hline Total & 278 & 100 \\
Working shifts: & & \\
Morning & 277 & 99.6 \\
Night & 1 & 0.4 \\
Afternoon & 0 & 0.00 \\
More than one shift & 0 & 0.00 \\
Others & 0 & 0.00 \\
\hline Total & 278 & 100
\end{tabular}

Daily working hours:

\begin{tabular}{lcc}
8 hours & 120 & 43.5 \\
12 hours & 158 & 56.8 \\
\hline \multirow{2}{*}{ Total } & 278 & 100
\end{tabular}

Body posture during working hours:

\begin{tabular}{lll} 
Sitting & 6 & 2.1 \\
Standing & 224 & 80.6 \\
Bending for long periods & 48 & 17.3 \\
\hline Total & 278 & 100
\end{tabular}

Problems at work:

\begin{tabular}{lll} 
Yes & 195 & 70.1 \\
No & 83 & 29.9 \\
\hline Total & 278 & 100 \\
These problems: & & \\
Work is difficult & 96 & 49.2 \\
Bad communication of managers & 73 & 37.5 \\
No enough salary & 26 & 13.3 \\
Others & 0 & 0.00 \\
\hline Total & 195 & 100
\end{tabular}

Consequences to improper work environment:

\begin{tabular}{lll} 
Fractures & 48 & 19.5 \\
Wounds & 198 & 80.5 \\
Burn & 0 & 0.00 \\
Others & 0 & 0.00 \\
\hline Total & 246 & 100 \\
\hline
\end{tabular}


Table (3): Frequency distribution of workers life style $(\mathrm{N}=278)$.

\begin{tabular}{|c|c|c|}
\hline Type of daily physical effort & No. & $\%$ \\
\hline Sports & 14 & 5.1 \\
\hline Work effort & 264 & 94.9 \\
\hline \multicolumn{3}{|l|}{ Types of sports: } \\
\hline Football & 11 & 78.6 \\
\hline Walking or running & 3 & 21.4 \\
\hline Swimming & 0 & 0.00 \\
\hline Others & 0 & 0.00 \\
\hline \multicolumn{3}{|l|}{ Practice this effort regularly: } \\
\hline Yes & 271 & 97.5 \\
\hline No & 7 & 2.5 \\
\hline Total & 278 & 100 \\
\hline \multicolumn{3}{|l|}{ Meals per day: } \\
\hline Two meals & 51 & 18.4 \\
\hline Three meals & 205 & 73.7 \\
\hline Four meals & 22 & 7.9 \\
\hline Others & 0 & 0.00 \\
\hline Total & 278 & 100 \\
\hline \multicolumn{3}{|l|}{ Eat healthy food: } \\
\hline Yes & 175 & 62.9 \\
\hline No & 40 & 14.4 \\
\hline Do not know & 63 & 22.7 \\
\hline Total & 278 & 100 \\
\hline \multicolumn{3}{|l|}{ Breakfast regularly: } \\
\hline Yes & 266 & 95.7 \\
\hline No & 12 & 4.3 \\
\hline Total & 278 & 100 \\
\hline \multicolumn{3}{|l|}{ Hours of sleep: } \\
\hline More than 6 hours & 229 & 82.4 \\
\hline Less than 6 hours & 49 & 17.6 \\
\hline Total & 278 & 100 \\
\hline
\end{tabular}

Table (4): Correlation between demographic data of workers and knowledge and self reported practices $(\mathrm{N}=278)$.

\begin{tabular}{lll}
\hline Demographic data & $\begin{array}{c}\text { Knowledge } \\
p \text {-value }\end{array}$ & $\begin{array}{c}\text { Self practices } \\
p \text {-value }\end{array}$ \\
\hline Worker's gender & $0.0001^{*}$ & 0.9 \\
Worker's age & $0.03^{*}$ & $0.0001^{*}$ \\
Worker's educational level & $0.0001^{*}$ & $0.0001^{*}$ \\
Monthly income & 0.4 & 0.2 \\
Marital status & 0.4 & 0.06 \\
\hline
\end{tabular}

Table (5): Relation between knowledge, health habits and practice levels of the workers $(\mathrm{N}=278)$.

\begin{tabular}{ll}
\hline Variable & $\begin{array}{l}\text { Practice } \\
p \text {-value }\end{array}$ \\
\hline Knowledge & $0.0001^{*}$ \\
Meals per day & $0.003^{*}$ \\
Daily physical effort & $0.001^{*}$ \\
Regular effort? & $0.011^{*}$ \\
Eat healthy food? & $0.001^{*}$ \\
Eat breakfast regularly & 0.2 \\
Hours of sleep & $0.02^{*}$ \\
\hline
\end{tabular}

\section{Discussion}

Workers in the poultry slaughterhouse are permanently exposed to health hazards. These have either a physical, chemical, mechanical, psychological or biological nature. Proper identification of these hazards is needed to avoid accidents and to prevent workers from exposure to hazards in their work. These workers are subject to many occupational hazards through air, water, soil and work procedures [13]. Workers in poultry processing slaughterhouses often lack understanding how to recognize and protect themselves from occupational health hazards they are exposed to on a daily basis. So there is a need to focus on workers safety to prevent work related diseases, injuries and promote their health [14]. One of the "root causes" of workplace injuries, illnesses, and incidents is the failure to identify or recognize hazards that are present, or that could have been anticipated. So a critical element of any effective safety and health program is a proactive, ongoing process to identify and assess such hazards. So that it is very necessary to assess workers perception of hazards they are daily exposed to during their work hours to be ready for controlling and preventing these hazards and consequently promoting workers' health and enhance productivity [15]. The result of the current study revealed that about half of workers aged more than 30 years. Such result was agree with results of a study done by Sutanto, on one hundred people of Jakarta Indonesia that found majority (48\%) of the participants aged between 25 and 39 years. From the research investigator point of view the age of workers sometimes could affect on the quality of performance due to many causes such as awareness, power and resources [16]. The result of the current study revealed that more than half of workers were males. This result congruent with the result of the study done by Musolin, et al., on 318 participants to study musculoskeletal disorders and traumatic injuries among employees at a Poul- 
try Processing Plant in South Carolina that found about seventy percent of study population were female. Form the research investigator point of view males could be the best workers especially for this kind of hard work because of their physical ability and power [4]. The results of the current study showed that more than half of workers had not enough income. From the research investigator point of view income affect workers' loyalty to work and their job satisfaction. The result of the current study showed that majority of workers was married. This result was supported by a study done by Burgus and Neetoo, on 150 participants in Mauritius that found sixty four percent of the participants was married. From the research investigator point of view marriage usually affect stability of work and compliance of workers to work instructions [17]. The result of the current study revealed that majority of workers had technical secondary education. This result was contradicted with a study done by Burgus and Neetoo, on 150 participants in Mauritius that found twenty eight percent of the participants had secondary education. From the research investigator point of view educational level sometimes affect the quality of performance in presence of the awareness toward any type of hazard they exposed to [17].

The current study results also revealed that about half of workers work more than five years at poultry slaughterhouses. This result supported by Musolin, et al., who found that participants worked at the plant for an average of eight years. From the research investigator point of view the length and duration of working at poultry slaughterhouses will affect workers' health status and complains [4]. The result of the current study revealed that majority of workers work eight hours per day. This results supported by the study of Leahy on 122 participants to study "an Assessment of Occupational Exposure to Gram-Negative Organisms in an Urban Poultry Slaughter and Processing Plant in Columbia" that found majority of the participant (79.6\%) work eight hours per day [18] The result of the current study revealed that majority of workers work at morning (morning shifts). This results supported by the study of Leahy, that found majority of the participant $(80.6 \%)$ work morning shifts [18]. The results of the current study also illustrated that majority of workers stand all time during work. From the research investigator point of view this directly affects their health, comfort, performance and elevates musculoskeletal problems. The results of the current study also illustrated that majority of workers mentioned having problems at work such as work is difficult (as reported by about half of workers), bad communication (as reported by more than one third of workers) and not enough salary. From the research investigator point of view these problems may affect on their performance and consequently on productivity. The results also showed that majority of workers had exposed to consequences due to improper work environment such as wounds (as reported by majority of workers) and fractures (as reported by around one quarter of workers). This result contradict the result of the study done by Musolin, et al., that found that seven percent of workers had injured during working procedures. From the research investigator point of view this directly related to lack of workers awareness to hazards, faulty manual practices and lack of occupational safety and health training for prevention of these hazards [4].

Regarding levels of knowledge and self reported practices, results of the current study show that majority of workers have unsatisfactory level of knowledge while twenty eight point one percent of them have satisfactory level of knowledge. These results contradict the result of the study done by Galizzi \& Tempesti to study workers' perceptions of risk and occupational injuries that found seventy nine point three percent of workers have satisfactory level of knowledge. From my point of view this is a result of absence of safety and training programs [19]. In addition results of the current study show that majority of workers have unsatisfactory level of practices while nineteen point four percent of them have satisfactory level of practice. From my point of view this is an automatic and natural response to lack of knowledge toward hazards as if they perceive it, they can avoid it.

Regarding correlation between demographic characteristics of workers and their knowledge, result of the current study revealed that there was a highly statistical significant correlation between worker's gender and knowledge where male has satisfactory knowledge than female. From my point of view this is directly because male has free time to learn more than female as they are less occupied. The results revealed highly statistical significant correlation between worker's age and knowledge also a highly significant correlation between worker's age and practice. From the research investigator point of view age of workers affect their ability to acquire general knowledge, increase their awareness and enhance their practices and performance. The results also show highly significant correlation between worker's educational level and knowledge 
and practices. From the research investigator point of view workers' educational level usually affect level of knowledge and in response reflected in their practices.

Regarding correlation between knowledge and practice levels of the workers, result of the current study revealed that there was a highly statistical significant correlation between worker's level of knowledge and worker's level of practices. Also there was a highly statistical significant correlation between number of meals per day and self reported practices. Moreover there was a highly statistical significant correlation between worker's daily physical effort and practices. In addition there was a highly statistical significant correlation between worker's regular effort and practices. Furthermore there was a highly statistical significant correlation between eating healthy food and self reported practices. Moreover there was a highly statistical significant correlation between worker's hours of sleep and self reported practices. While there was no statistical significant correlation found between workers who eat breakfast regularly and self reported practices. From the research investigator point of view worker who don't know the importance or hazard will never perform tasks safely.

\section{Conclusion:}

The study concluded that, workers had unsatisfactory level of perception (knowledge and self reported practices) regarding occupational health hazards they are exposed to.

\section{Recommendations:}

Based on the findings of this study, the following are recommended:

1- Developing occupational health programs to increase knowledge and practices of workers in order to ensure positive perception.

2- Activate the role of the occupational health nurse in such high risk workplaces through applying frequent educational sessions about occupational hazards, workers' safety and preventive measures of these occupational health hazards.

3- Activate the role of supervision to achieve workers' compliance.

4- Policies, procedures and roles related to occupational health should be applied in different slaughterhouses.

5- Further researches are needed to assess perception of poultry workers about occupational hazards and ensure safety a nd health measures of workers in different slaughterhouses.

\section{References}

1- GORMAN T. and KAMEN J.: Standards of Occupationa and environmental health nursing (2 nd ed); pp 4. Atlanta, DC. American Association of Occupational Health Nurses (AAOHN), 2013.

2- MOJTABA Y.: Occupational and environmental hazards among poultry Processing workers. World Poultry \& Ontario Ministry of Labour, 2014.

3- Center for Disease Prevention and Control \& NIOSH Health Hazards Evaluation Report: Campylobacter Infection and Exposures among Employees at a Poultry Processing Plant. Available online at: http://www.cdc.gov/niosh/ topics/poultry /slaughter. html, 2013.

4- MUSOLIN K., RAMSEY J., JAMES W., DAVID H. and CHARLES M.: Evaluation of Musculoskeletal Disorders and Traumatic Injuries Among Employees at a Poultry Processing Plant. Department of Health and Human Services, Centers for Disease Control and Prevention \& National Institute for Occupational Safety and Health, 2014.

5- The Bureau of Labor Statistics: Work-related musculoskeletal disorders at Poultry processing plant. U.S. Center to Protect Workers' Rights, 2013.

6- FRANK R.S. and REVONNA M.B.: Occupational Safety and Health Simplified for the Food Manufacturing Industry. Government Institutes An imprint of The Scarecrow Press, Inc. Lanham, Maryland. Toronto. Plymouth, UK, 2011.

7- BRIAN D.L.: Accurate and Efficient Assessments of Working Posture. Centers for Disease Control and Prevention, 2014.

8- The Bureau of Labor Statistics: Work-related musculoskeletal disorders at Poultry processing plant.U.S. Center to Protect Workers' Rights, 2013.

9- ANAEJIONU R.: Perception vs. Reality in the Workplace. Demand Media. Hearst Newspapers. Available online at: http: //smallbusiness.chron. Com/perception-vs-realityworkplace-11364.html, 2015.

10- MOJTABA Y.: Occupational and environmental hazards among poultry Processing workers. World Poultry \& Ontario Ministry of Labour, 2014.

11-EMELDA M.: Difference between Developed and Developing Countries; ISSN 2222-1905 (Paper) ISSN 2222 Vol. 5, No.3. European Journal of Business and Management available online at: www.iiste.org , 2013.

12- MUSOLIN K., RAMSEY J., JAMES W., DAVID H. and CHARLES M.: Evaluation of Musculoskeletal Disorders and Traumatic Injuries Among Employees at a Poultry Processing Plant. Department of Health and Human Services, Centers for Disease Control and Prevention \& National Institute for Occupational Safety and Health, 2014.

13- MARCHYSHYNA Y.I., MELNYK V.V. and GRECHYSHYN O.M.: Occupational hazards in the poultry farms. National university of life and Environmental sciences of Ukraine, 2015.

14- HUNTER D. and SILVERSTEIN B.: Perception of risk from workers in high risk industries with work related 
musculoskeletal disorders. A Journal of prevention, Assessment and Rehabilitation, 2014.

15- United States Department of Labor: Hazard Identification and Assessment .Occupational Safety and Health Administration. Available on line at www.OSHA.gov, 2017.

16- SUTANTO Y.C.: Highly Pathogenic Avian Influenza Knowledge, Attitudes, And Practices Study Among Live Bird Market Workers in Jakarta-Indonesia. Department of Clinical Sciences. Colorado State University, 2013.

17- BURGUS H. and NEETOO H.: A Study on Food Safety
Knowledge and Perceptions among Poultry workers in Mauritius. Department of Agriculture and Food Science, Faculty of Agriculture, University of Mauritius, 2016.

18- LEAHY K.: An Assessment of Occupational Exposure to Gram-Negative Organisms in an Urban Poultry Slaughter and Processing Plant in Columbia. Johns Hopkins University, 2015.

19- GALIZZI M. and TEMPESTI T.: Workers' perceptions of risk and occupational injuries. Department of Economics, University of Massachusetts Lowell, 2014. 


\section{المخاطر الصحية المهنية كما يدركها عمال المجازد الآلية للدواجن بمحافظة المنوفية يلمانية}

المقدمة: يتعرض عمال المجازر الآلية للدواجن بشكل دائم المخاطر الصحية المهنية والبيئية خلال خطوات تجهيز الدواجن على آساس

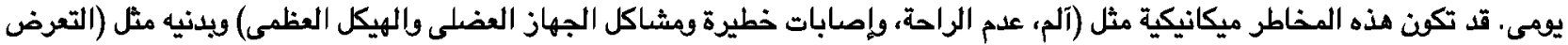

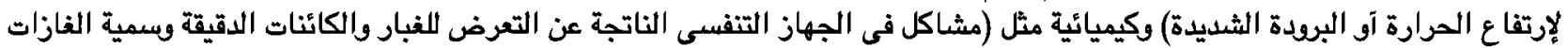

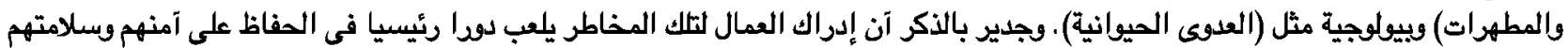

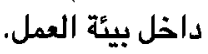

الهدف من البحث: يهدف هذا البحث إلى تقييم المخاطر الصحية المهنية كما يدركها عمال المجان الآلية للدواجن بمحافظة المنفية.

$$
\text { تصميم البحت: إستخدام المنهج الوصفى لتحقيق هدف الدراسة. }
$$

عينة الدراسة: شملت عينة الجحث rVA عامل من عمال المجازر الآلية للدواجن.

مكان البحث:تم تنفيذ هذا البحث فى مجز آلى بمحافظة المنوفية.

آدوات البحث: آداة واحدة تكونت من آريع آجزاء:

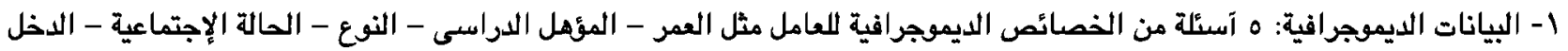

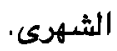

ז- التاريخ المرضى والههنى اللعامل: تثمل 17 سؤال عن ورديات العمل - عدد ساعات العمل - مدة العمل فى المجازر - الحوادث آثناء العمل

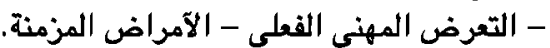

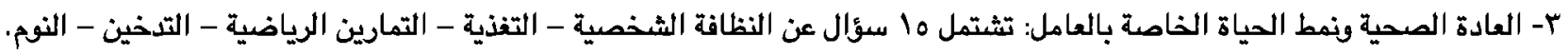
ع- إدراك العمال للمخاطر الصحية المهنية: تشمل Oب سؤال عن معلومات العامل عن المخاطر - الممارسات الذاتية للعامل.

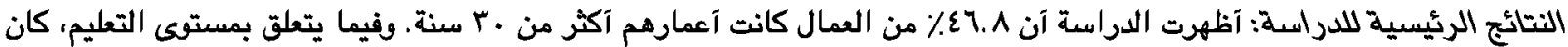

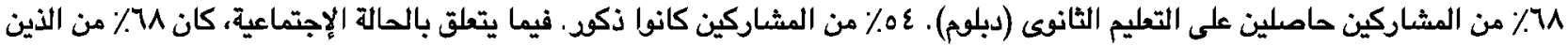

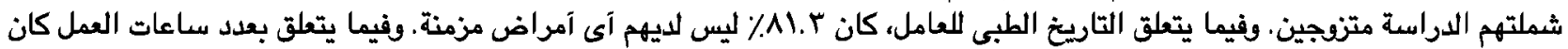

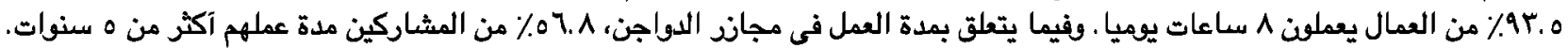

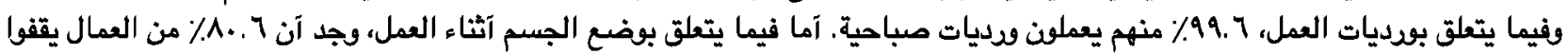

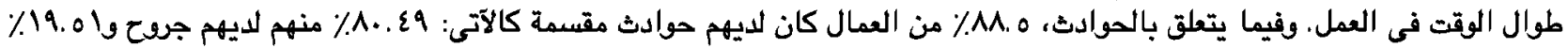

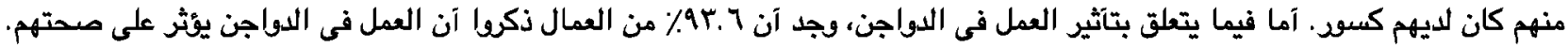

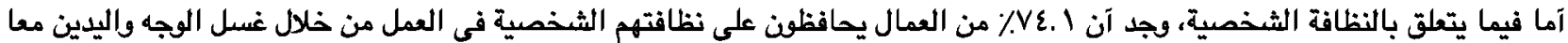

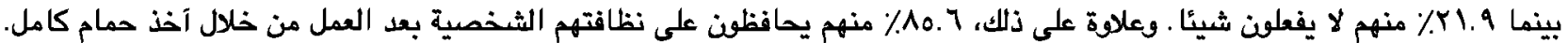

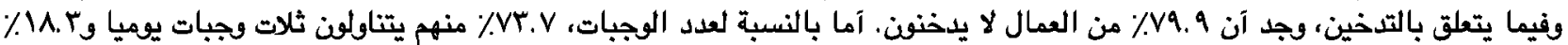

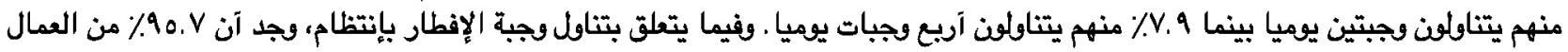

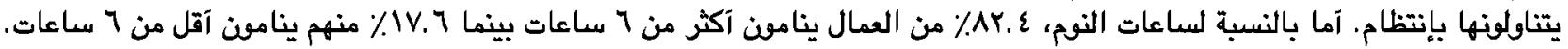

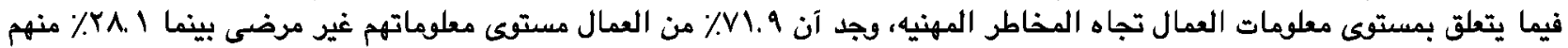

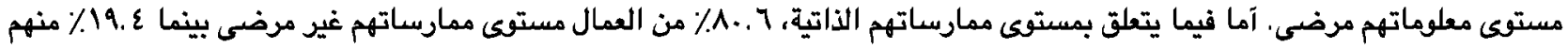

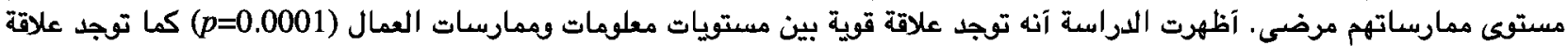

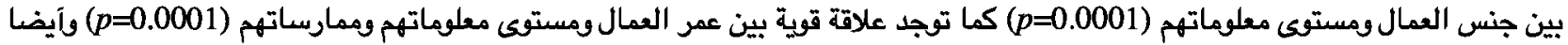

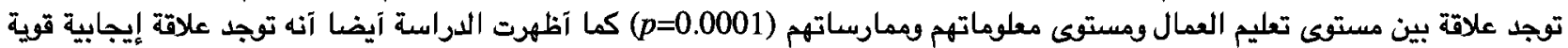

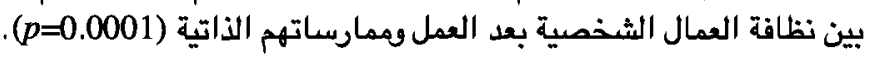

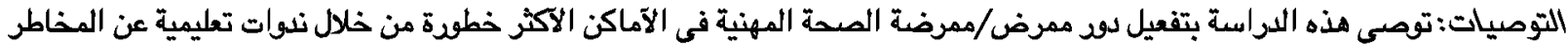

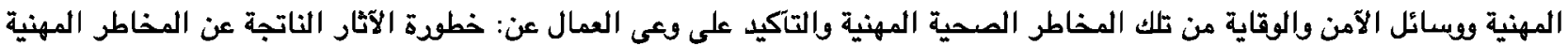

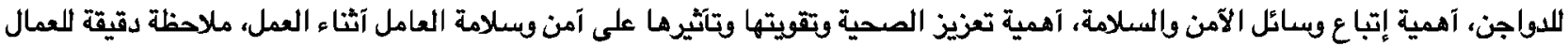

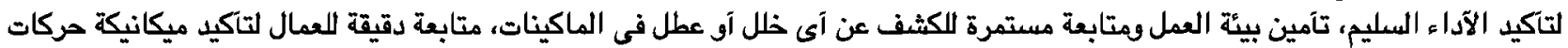

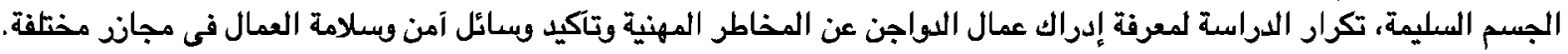

